Review Article

\title{
The Application of Citrus folium in Breast Cancer and the Mechanism of Its Main Component Nobiletin: A Systematic Review
}

\author{
Yuan Wu $\mathbb{D},{ }^{1}$ Chien-shan Cheng $\mathbb{D},{ }^{2,3}$ Qiong Li $\mathbb{D}^{1},{ }^{1}$ Jing-xian Chen $\mathbb{D}^{1},{ }^{1}$ Ling-ling $L v \mathbb{D}^{1}$ \\ Jia-yue Xu $\mathbb{C}^{1},{ }^{1}$ Kai-yuan Zhang $\left({ }^{1},{ }^{1}\right.$ and Lan Zheng $\mathbb{D}^{1}$ \\ ${ }^{1}$ Department of Traditional Chinese Medicine, Shanghai Jiao Tong University School of Medicine Affiliated Ruijin Hospital, \\ Shanghai 200025, China \\ ${ }^{2}$ Department of Integrative Oncology, Fudan University Shanghai Cancer Center, Shanghai 200032, China \\ ${ }^{3}$ Department of Oncology, Shanghai Medical College, Fudan University, Shanghai 200032, China
}

Correspondence should be addressed to Lan Zheng; windy9453@126.com

Received 29 April 2021; Revised 28 May 2021; Accepted 19 June 2021; Published 29 June 2021

Academic Editor: Juntra Karbwang

Copyright $\odot 2021$ Yuan Wu et al. This is an open access article distributed under the Creative Commons Attribution License, which permits unrestricted use, distribution, and reproduction in any medium, provided the original work is properly cited.

Citrus folium and its main ingredient nobiletin (NOB) have received widespread attention in recent years due to their antitumor effects. The antitumor effect of Citrus folium is related to the traditional use, mainly in its Chinese medicinal properties of soothing the liver and promoting qi, resolving phlegm, and dispelling stagnation. Some studies have proved that Citrus folium and NOB are more effective for triple-negative breast cancer (TNBC), which is related to the syndrome of stagnation of liver qi. From the perspective of modern biomedical research, NOB has anticancer effects. Its potential molecular mechanisms include inhibition of the cell cycle, induction of apoptosis, and inhibition of angiogenesis, invasion, and migration. Citrus folium and NOB can also reduce the side effects of chemotherapy drugs and reverse multidrug resistance (MDR). However, more research studies are needed to clarify the underlying mechanisms. The modern evidence of Citrus folium and NOB in breast cancer treatment has a strong connection with the traditional concepts and laws of applying Citrus folium in Chinese medicine (CM). As a low-toxic anticancer drug candidate, NOB and its structural changes, Citrus folium, and compound prescriptions will attract scientists to use advanced technologies such as genomics, proteomics, and metabolomics to study its potential anticancer effects and mechanisms. On the contrary, there are relatively few studies on the anticancer effects of Citrus folium and NOB in vivo. The clinical application of Citrus folium and NOB as new cancer treatment drugs requires in vivo verification and further anticancer mechanism research. This review aims to provide reference for the treatment of breast cancer by Chinese medicine.

\section{Introduction}

According to the latest data from the International Agency for Research on Cancer (IARC) in 2018, the incidence of breast cancer (BC) in female cancers worldwide is $24.2 \%$, ranking first among female cancers, which is the main cause of female cancer deaths [1]. In the early stage, symptoms such as breast lumps, nipple discharge, and axillary lymphadenopathy are often manifested. In the late stage, cancer cells may metastasize to a distance, and multiple organ diseases may appear, which directly threaten the life of the patient. Although radiotherapy, chemotherapy [2], and immunotherapy [3] can inhibit the further growth and proliferation of tumors to achieve the purpose of suppressing tumors, they have large toxic side effects, such as bone marrow suppression [4], allergic symptoms [5], skinrelated symptoms [6], and gastrointestinal distress [7]. There are still certain limitations in postoperative tumor recurrence, bone metastasis, and multidrug resistance (MDR) [8-10]. Therefore, it is very important to find a way to reduce toxic side effects and increase sensitivity.

As one of the main complementary and alternative medicines, traditional Chinese medicine (TCM) has a history of thousands of years [11]. It has the advantages of 
multiple targets, small side effects, and significant clinical effects in cancer treatment [12-15]. Drug screening from natural medicines is a feasible shortcut, such as paclitaxel extracted from Taxus mairei [16], Kanglaite injection extracted from Coix lachryma-jobi semen [17], and Cinobufacini extracted from Toad skin cutis bufonis [18]. We have discovered from the compound prescriptions that Citrus folium is commonly used to treat $\mathrm{BC}$ as Chinese medicine (CM). Citrus folium is derived from the leaves of the Rutaceae plant Tangerine and its cultivated varieties. It has the effects of soothing the liver, promoting qi, removing phlegm, and resolving mass. Modern pharmacological studies have shown that Citrus folium mainly contains volatile oil, carbohydrates, flavonoids, and other ingredients, which can effectively treat cough, pulmonary carbuncle, breast carbuncle, hypochondriac pain, abdominal distension, hernia, edema, etc. [19]. However, the material basis of its efficacy is still unclear, so the mechanism of BC treatment at the molecular level is worthy of further study.

NOB is one of the main components of Citrus folium, with a content of about $1.94 \%$ [20], which is essentially polymethoxyflavones (PMFs) [21]. Because of its more methoxy groups, it has high-fat solubility. The molecular formula is $\mathrm{C}_{21} \mathrm{H}_{22} \mathrm{O}_{18}$, and the weight is $402.399 \mathrm{~g} / \mathrm{mol}$. Its structure is shown in Figure 1. In addition to separating NOB from Citrus folium, there is also a small amount of NOB in Citri reticulate pericarpium [22]. Experimental studies in vivo and in vitro have confirmed that NOB has a wide range of effects, including anti-inflammatory [23-25], antiviral [26, 27], inhibition of oxidative stress [27], antiatherosclerosis [28], nerve protection [29-31], antidementia $[32,33]$, alleviation of ischemia-reperfusion injury $[34,35]$, and antidiabetic [36]. Not only that, NOB is also quite significant in the tumor treatment, including nasopharyngeal cancer [37], breast cancer [38], lung cancer [39], gastric cancer [40], colorectal cancer [41], liver cancer [42], prostate cancer [43], kidney cancer [44], bladder cancer [45], ovarian cancer [46], glioma [47], osteosarcoma [48], and other different types. It can inhibit tumor cell growth and proliferation [49], can inhibit invasion and migration by inhibiting EMT [39, 50] and angiogenesis [51], regulates the tumor cell cycle to block it in the G1 phase [51], and can induce apoptosis, which can be used to "precise" the treatment of tumors in terms of tumorigenesis, promotion, and prognosis. Since the source of NOB is Citrus folium, which is often used to treat $\mathrm{BC}$ in $\mathrm{CM}$, we decided to study the mechanisms of NOB in the BC treatment.

Based on the combination of prescriptions and syndromes, we found that Citrus folium is mostly used to treat BC. Therefore, we review the traditional use history of Citrus folium, from the clinical application of Citrus folium to the pharmacological research of $\mathrm{NOB}$, focusing on the anti-BC effects and their prospects as new antitumor drugs.

\section{Research Methodology}

This review was conducted following the Preferred Reporting Items for Systematic Reviews and Meta-Analyses (PRISMA) statement [52].

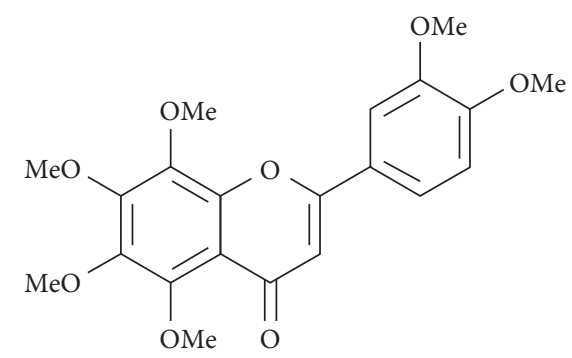

FIgURE 1: The chemical construction of NOB.

2.1. Search Strategy. Every publication in English that was reviewed for this study was extracted from the PubMed, Embase, Web of Science, and CNKI databases restricted to the Medical Subject Headings Index (MeSH/DeCS) to April 2021. The search was based on different combinations of the following keywords: "Citrus folium," "Folium citrus reticulate," "nobiletin," "NOB," "mechanism," "anti-breast-cancer," and "pharmacology." Furthermore, we reviewed the references in the selected articles for additional reports not included in the original article search.

2.2. Study Selection. The two authors independently extracted and proofread the titles and abstracts of each article. The inclusion criteria were the mechanism of Citrus folium and NOB in the treatment of breast cancer, including in vivo and in vitro models. The authors excluded articles based on the following criteria: review articles, abstracts, editorials/letters, conference proceedings, case reports, and the content not related to cancer. Differences of opinion between two authors were determined independently by the third author. The flow of the literature search is presented in Figure 2 .

\section{Results}

\subsection{TCM Understanding of the Etiology and Pathogenesis of $B C$}

3.1.1. Ancient Chinese Medicine's Views on BC. In different historical periods, Chinese physicians have different understandings of the etiology and pathogenesis of BC. During the Jin, Sui, and Tang Dynasties, most physicians believed that the tumorigenesis and progression of $\mathrm{BC}$ were related to qi stagnation and blood stasis; during the Song, Jin, and Yuan Dynasties, physicians emphasized the effects of internal emotional injuries, the liver-spleen disharmony, and qi-blood deficiency; in the Ming and Qing Dynasties, the etiology and pathogenesis of BC were mainly liver dysfunction, lack of kidney qi, and imbalance of thoroughfare vessel (Chong channels) and conception vessel (Ren channels) [53]. We found that the understanding of $\mathrm{BC}$ in different historical periods has one thing in common: stagnation of liver qi, indicating that qi stagnation is the main cause of most breast cancers.

For example, for the pathogenesis of BC, Chen Shigong described it in detail in Orthodox Manual of External Medicine (Wai Ke Zheng Zong, Ming Dynasty, AD 1617) 


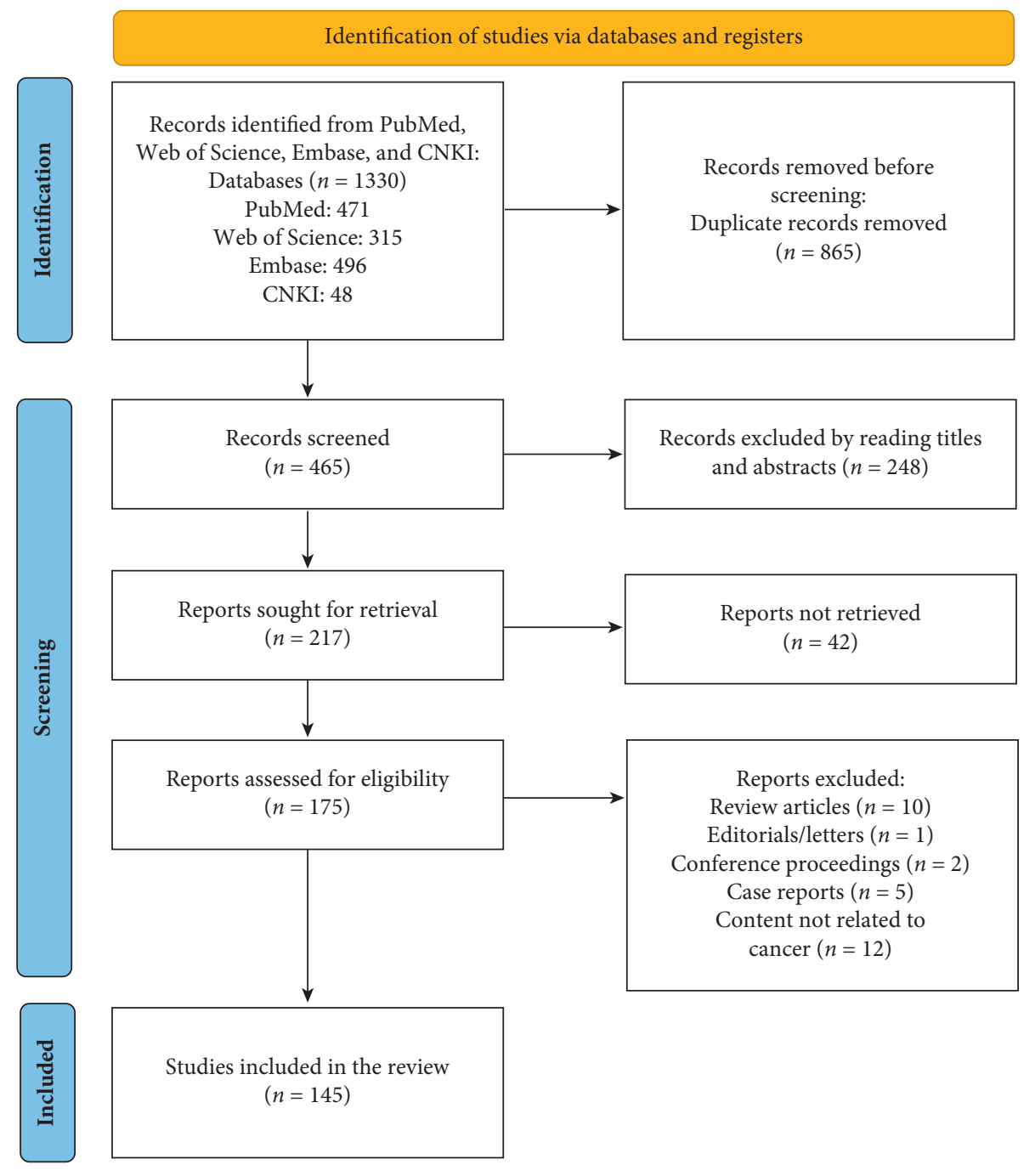

Figure 2: The flow of the literature search.

[54]: "the etiology of BC is that depression causes liverspleen disharmony, then the viscera is weak, which eventually leads to breast lumps like stones (Ru Yan)." In Collected Works of Materia Medica (Ben Cao Hui Yan, Ming Dynasty, AD 1624), the etiology of breast tumors is described: "blood-qi stagnation, and the accumulation of phlegm and saliva, lead to hypochondriac pain, mammary carbuncle, swelling toxin and other diseases [55]." According to the theory of TCM, the main reason for the formation of $\mathrm{BC}$ is an emotional injury such as depression and anxiety and visceral dysfunction which causes phlegm accumulation and blood stasis in the breast, eventually leading to breast cancer. Therefore, the initial cause of BC is emotional injury.

3.1.2. Modern Chinese Medicine's Views on BC. Modern Chinese medicine also believes $\mathrm{BC}$ is closely related to qi and blood. According to the classification of BC syndromes in the "Standards of Chinese Society of Chinese Medicine/ Guidelines for the Diagnosis and Treatment of Tumors in TCM," 2008 edition [56], they are divided into the stagnation of liver-qi, accumulation of heat-induced toxicity, thoroughfare vessel (Chong channels) and conception vessel (Ren channels) disorder, deficiency of both qi and blood, spleen and stomach weakness, and yin deficiency of the liver and kidney. Through the analysis of the BC research literature, we summarize the distribution characteristics of its common syndromes and general symptoms (as shown in Table 1). With the tumorigenesis, promotion, and metastasis of $\mathrm{BC}$, the main syndrome differentiation types in each process are different. The early stage is mostly qi stagnation and blood stasis, accumulation of phlegm and dampness, and heat-induced toxicity [57]. In the later stage and after metastasis, they are mostly yin deficiency of the liver and kidney, yang deficiency of the spleen and kidney [58], and vital qi insufficiency.

3.1.3. The Connection between TCM and Western Medicine about the Tumorigenesis of BC. The essence of tumorigenesis is gene mutation, which is closely related to the constitution of TCM [59]. Certain constitution such as deficiency of vital qi are high risk factors for $\mathrm{BC}$ [60]. The study found that the BRCA 
TABle 1: The syndrome of BC in TCM.

\begin{tabular}{|c|c|c|c|c|}
\hline Syndromes & Symptoms & Tongue and pulse & Main symptoms & Stage \\
\hline $\begin{array}{l}\text { Disharmony of the } \\
\text { thoroughfare vessel (Chong } \\
\text { channels) and conception } \\
\text { vessel (Ren channels) }\end{array}$ & $\begin{array}{c}\text { Menstrual changes, lassitude, tidal fever } \\
\text { and night sweating, soreness and } \\
\text { weakness of the waist and knees, } \\
\text { irritability, dry mouth, anorexia, } \\
\text { dizziness }\end{array}$ & $\begin{array}{l}\text { Light color of the } \\
\text { tongue, thin fur, wiry } \\
\text { pulse, thread pulse }\end{array}$ & $\begin{array}{l}\text { Menstrual changes, tidal fever } \\
\text { and night sweating, dry } \\
\text { mouth }\end{array}$ & I \\
\hline Stagnation of liver qi & $\begin{array}{l}\text { Depression, hypochondrium distending } \\
\text { pain, soreness and weakness of the waist } \\
\text { and knees, menstrual changes }\end{array}$ & $\begin{array}{l}\text { Reddish tongue, thin } \\
\text { fur, wiry pulse, thread } \\
\text { pulse }\end{array}$ & $\begin{array}{l}\text { Hypochondrium distending } \\
\text { pain, depression }\end{array}$ & I \\
\hline $\begin{array}{l}\text { Vital qi insufficiency and heat } \\
\text { flourishing }\end{array}$ & $\begin{array}{l}\text { Irritability, menstrual changes, lassitude, } \\
\text { anorexia, soreness and weakness of the } \\
\text { waist and knees, insomnia }\end{array}$ & $\begin{array}{l}\text { Light color of the } \\
\text { tongue, yellow and } \\
\text { greasy fur, wiry pulse, } \\
\text { thread pulse, weak pulse }\end{array}$ & $\begin{array}{l}\text { Lassitude, tidal fever, yellow } \\
\text { fur }\end{array}$ & II \\
\hline Qi and Yin deficiency & $\begin{array}{l}\text { Lassitude, depression, menstrual } \\
\text { changes, anorexia, tidal fever and night } \\
\text { sweating, dry and itchy throat, insomnia }\end{array}$ & $\begin{array}{l}\text { Light color of the } \\
\text { tongue, wiry pulse, } \\
\text { thread pulse }\end{array}$ & $\begin{array}{l}\text { Lassitude, tidal fever, and } \\
\text { night sweating }\end{array}$ & $\begin{array}{l}\text { III } \\
\text { IV }\end{array}$ \\
\hline $\begin{array}{l}\text { Yin deficiency of the liver and } \\
\text { kidney }\end{array}$ & $\begin{array}{l}\text { Lassitude, soreness, and weakness of the } \\
\text { waist and knees, insomnia, dizziness, dry } \\
\text { and itchy throat, tidal fever and night } \\
\text { sweating, tinnitus, forgetfulness }\end{array}$ & $\begin{array}{l}\text { Reddish tongue, thin } \\
\text { fur, wiry pulse, thread } \\
\text { pulse }\end{array}$ & $\begin{array}{l}\text { Soreness and weakness of the } \\
\text { waist and knees, insomnia, } \\
\text { tidal fever, tinnitus }\end{array}$ & $\begin{array}{l}\text { III } \\
\text { IV }\end{array}$ \\
\hline
\end{tabular}

gene mutation rate of TNBC was $11.2 \%$ [59]. Professor Wan believes that it is consistent with the concept of congenital deficiency in TCM [61].

Negative emotions, as a stressor of the human body, affect its endocrine, nervous, and immune systems and increase the rate of recurrence and metastasis of $\mathrm{BC}$ [62]. By activating the renin-angiotensin system, it promotes the secretion of adrenal corticosterone, reduces the activity of NK cells, and ultimately weakens the patient's immune supervision ability [63]. This is the same as the etiology and pathogenesis of the "stagnation of liver qi" in TCM.

Modern medicine believes that increased intake of high-fat diet is related to the incidence of BC. It has been reported that long-term intake of high fat will increase the risk of $\mathrm{BC}$ and show a certain dose effect [64]. There is also evidence that Asian postmenopausal women who prefer "meat-sweet food" diets have a ratio of 1.3 associated with $\mathrm{BC}$ risk [65]. Phlegm stagnation caused by unregulated diet is indeed related to the microenvironment of BC. In breast tumors, adipose tissue occupies a large proportion in the interstitium, forming a unique tumor-associated adipose tissue (CAAT), which is the fat microenvironment around the tumor [66]. Adipocytes can abnormally secrete tumor-related adipokines and a large number of metabolic substrates, providing energy for tumor cell proliferation and migration [67]. Adipokines and metabolic substrates are the "turbid toxins" of TCM, which are difficult to transfer normally, and can be transformed into lumps [68]. They are not only a pathogenic factor of $\mathrm{BC}$ but also provide a material basis for the tumor microenvironment.

Breast cancer is prone to lung metastasis and brain metastasis $[69,70]$. This is closely related to the stagnation of qi due to phlegm, phlegm-dampness obstructing the lung, and the orifices confused by phlegm. It also shows the process of phlegm syndrome from shallow to deep, from light to severe. In addition, bone metastasis is related to the disharmony between nutritive qi and defensive qi. The ability of blood to nourish bones and defensive qi to resist exogenous pathogens decreases, causing BC cytokines to interact with cells in the bone microenvironment, thereby triggering bone metastasis [71].

Based on the high-risk factors of breast cancer, we tried to explain the similarities between the etiology and pathogenesis of TCM and the pathophysiology of Western medicine in the tumorigenesis.

It can be seen from Table 1 that the pulses of all syndrome types are wiry and thread pulses (Xi and Xian Mai), indicating that the tumorigenesis of the breast is related to the stagnation of liver qi. Citrus folium can promote qi and dispel stagnation, so it is mainly used to treat the qi stagnation type of BC. However, the combination of diseasesyndrome-prescriptions and molecular research is still lacking, so we summarized the application of Citrus folium in different prescriptions and the molecular mechanism of its main component NOB.

3.2. The Application of Citrus folium in the Treatment of BC in TCM. The record of Citrus folium can be traced back to Addendum to the Derivation of Herbs (Ben Cao Yan Yi Bu Yi, Yuan Dynasty, AD 1347) compiled by Zhu Danxi. The description of the nature and flavor of Citrus folium is in Compendium of Materia Medica (Ben Cao Gang Mu, Ming Dynasty, AD 1596) [72]. The large-scale use of Citrus folium was in the Ming and Qing Dynasties, such as Bamboo women's region (Zhu Lin Nv Ke, Qing Dynasty, AD 1817), wrote by the famous CM physician, Ye Tianshi, which pointed out that Citrus folium can be used to treat breast cancer (Ru Yan) [73]. In addition to the traditional oral form, Citrus folium can also be used externally. Citrus folium has many traditional formulas for treating BC (as shown in Table 2), and most of the corresponding syndromes are liverqi stagnation.

Most of the modern Chinese patent medicine preparations for the treatment of breast lumps contain Citrus 
TABLE 2: The summary of Citrus folium treating breast-related diseases.

\begin{tabular}{|c|c|c|c|c|c|}
\hline Source & Prescription & Composition & $\begin{array}{c}\text { Name of the } \\
\text { disease }\end{array}$ & Syndrome type & References \\
\hline $\begin{array}{l}\text { Experience Gained in } \\
\text { Treating External Diseases } \\
\text { (Yang Ke Xin de Ji, Qing } \\
\text { Dynasty, AD 1805) }\end{array}$ & $\begin{array}{l}\text { Citrus folium } \\
\text { decoction }\end{array}$ & $\begin{array}{l}\text { Citrus folium, Taraxaci cum radice } \\
\text { herba, Fritillariae thunberii bulbus, } \\
\text { Prunellae vulgaris spica, Citri } \\
\text { reticulatae viride pericarpium, } \\
\text { Angelicae sinensis corpus Radicis, } \\
\text { Paeoniae rubrae radix, Trichosanthis } \\
\text { kirilowii radix, Cyperi rotundi rhizoma, } \\
\text { Scutellariae baicalensis radix }\end{array}$ & $\begin{array}{c}\text { Breast } \\
\text { carbuncle }\end{array}$ & $\begin{array}{l}\text { Heat flourishing, } \\
\text { liver-qi stagnation }\end{array}$ & {$[74]$} \\
\hline $\begin{array}{l}\text { Wonders of Effective } \\
\text { Prescription (Qi Xiao Liang } \\
\text { Fang, Ming Dynasty, AD } \\
1520 \text { ) }\end{array}$ & $\begin{array}{l}\text { Forsythia } \\
\text { suspense } \\
\text { decoction }\end{array}$ & $\begin{array}{c}\text { Citrus folium, Forsythia suspense } \\
\text { Fructus, Liguszici, Trichosanthis semen, } \\
\text { Gleditsiae Sinensis Spina, Citri } \\
\text { reticulate viride pericarpium, } \\
\text { Glycyrrhizae uralensis praparatae } \\
\text { radix, Persicae semen }\end{array}$ & $\begin{array}{l}\text { Breast } \\
\text { carbuncle } \\
\text { Mammary } \\
\text { node }\end{array}$ & $\begin{array}{l}\text { Phlegm and blood } \\
\text { stasis, liver-qi } \\
\text { stagnation }\end{array}$ & {$[75]$} \\
\hline $\begin{array}{l}\text { Feng's Ace-Pack (Feng Shi Jin } \\
\text { Nang, Qing Dynasty, AD } \\
1722 \text { ) }\end{array}$ & $\begin{array}{l}\text { Citrus forsythia } \\
\text { decoction }\end{array}$ & $\begin{array}{c}\text { Citrus folium, Citri reticulate viride } \\
\text { pericarpium, Trichosanthis Fructus, } \\
\text { Forsythia suspense Fructus, Persicae } \\
\text { semen, Gleditsiae Sinensis Spina, } \\
\text { Bulpleuri radix, Glycyrrhizae } \\
\text { ureagenesis radix } \\
\end{array}$ & $\begin{array}{c}\text { Breast } \\
\text { carbuncle }\end{array}$ & $\begin{array}{l}\text { Heat flaming in } \\
\text { the beginning }\end{array}$ & {$[76]$} \\
\hline $\begin{array}{l}\text { Integration of Medicine (Yi } \\
\text { Xue Ji Cheng, Qing Dynasty, } \\
\text { AD 1873) }\end{array}$ & $\begin{array}{l}\text { Dissipating } \\
\text { nodules' } \\
\text { decoction }\end{array}$ & $\begin{array}{l}\text { Citrus folium, Taraxaci cum radice } \\
\text { herba, Cyperi rotundi rhizoma, } \\
\text { Liguszici, Angelicae dahuricae radix, } \\
\text { Fritillariae thunberii bulbus, Lonicerae } \\
\text { japonicae flos, Perillae frutescentis } \\
\text { folium, Alli fistulosi bulbus }\end{array}$ & $\begin{array}{l}\text { Mammary } \\
\text { node }\end{array}$ & $\begin{array}{l}\text { Heat flourishing, } \\
\text { liver-qi stagnation }\end{array}$ & {$[77]$} \\
\hline $\begin{array}{l}\text { Bamboo Women's Treatment } \\
\text { (Zhu Lin Nv Ke Zheng Zhi, } \\
\text { Qing Dynasty, AD 1817) }\end{array}$ & $\begin{array}{l}\text { Lonicerae } \\
\text { japonicae flos } \\
\text { decoction }\end{array}$ & $\begin{array}{c}\text { Citrus folium, Lonicerae japonicae flos, } \\
\text { Astragali membranacei radix, Angelicae } \\
\text { sinensis corpus radicis, Glycyrrhizae } \\
\text { uralenisis radix }\end{array}$ & Breast cancer & $\begin{array}{l}\text { Vital qi deficiency } \\
\text { and heat-induced } \\
\text { toxicity }\end{array}$ & {$[73]$} \\
\hline $\begin{array}{l}\text { Orthodox Manual of External } \\
\text { Medicine (Wai Ke Zheng } \\
\text { Zong, Ming Dynasty, AD } \\
\text { 1617) }\end{array}$ & $\begin{array}{l}\text { Citrus folium } \\
\text { powder }\end{array}$ & $\begin{array}{l}\text { Citrus folium, Bulpleuri radix, Citri } \\
\text { reticulate pericarpium, Liguszici, } \\
\text { Gardeniae jasminoidis Fructus, Citri } \\
\text { reticulate viride pericarpium, Gypsum, } \\
\text { Scutellariae baicalensis radix, Forsythia } \\
\text { suspense Fructus, Glycyrrhizae uralensis } \\
\text { praparatae radix }\end{array}$ & Breast cancer & $\begin{array}{l}\text { Heat flourishing, } \\
\text { liver-qi stagnation }\end{array}$ & {$[54]$} \\
\hline
\end{tabular}

folium, which is made into tablets, capsules, powders, liquid preparations, etc., including Rukuaixiao tablet, Rupikang tablet, and Lirukang capsule [78]. Most of the clinical empirical prescriptions of modern Chinese medicine for treating BC contain Citrus folium, such as prescription for regulating the liver and tonifying the kidney in our team [79]. However, TCM is not clear about the pathological nature of the disease, and the specific mechanism of Citrus folium in the treatment of $\mathrm{BC}$ needs to be studied on its active ingredient.

\subsection{Extraction Methods and Mechanisms of $\mathrm{NOB}$}

3.3.1. NOB Extraction Methods. To clarify the specific pathways for the effective components in Citrus folium to treat tumors, the researchers carried out alcohol extraction, chromatography, crystallization, etc., on Citrus folium and successfully separated and purified NOB $[80,81]$. Dong et al. used $95 \%$ ethanol to immerse and reflux the Citrus folium coarse powder, then used small-pore resin (MCI) column chromatography to preliminarily separate the ethanol extract, and finally purified NOB by silica gel, MCI, ODS, polyamide, Sephadex LH-20, and other column spectrum analyses [20]. There are usually many methods for extracting NOB. The most commonly used is the petroleum ether [82] solvent extraction method. It can also be extracted with acetone, absolute ethanol, methanol, ethyl acetate, etc. And ultrasonicassisted extraction can be used to improve efficiency [83] by destroying the cell membrane and accelerating cell lysis [84]. Chromatography can identify and quantitatively analyze flavonoids, such as column chromatography [85] and highspeed countercurrent chromatography $[86,87]$.

\subsubsection{Nobiletin's Mechanisms on Different Conduction} Pathways in BC. NOB plays a certain role in the BC treatment in many aspects, such as inhibition of tumor cell 
growth and proliferation, regulation of the tumor cell cycle, induction of tumor cell apoptosis, regulation of tumor-related protein expression, inhibition of migration and invasion, and inhibition of angiogenesis. The specific mechanisms and conduction pathways are summarized in Figure 3 and Table 3.

From Table 3, we can conclude that NOB can inhibit the phosphorylation of AKT and downstream mTOR in MDAMB-468 cells but does not inhibit the activity of these two molecules in other BC cell lines. Bcl and Bax were only involved in the apoptosis of MDA cells, but not in MCF-7 and SK-BR-3 cells [94]. It indicates that NOB may be more effective on the MDA-MB-468 cell line, which belongs to TNBC. In other words, NOB might be more effective for TNBC.

(1) Tumor Cell Growth Inhibition. The primary difference between tumor cells and normal cells is that the growth rate is greatly accelerated, and the number of tumor cells increases sharply in a short period. NOB showed a dose-dependent growth inhibitory activity on three types of BC cells. The largest growth inhibitory effect was observed in MDAMB-468, while in SK-BR-3, the lowest growth inhibitory effect was observed [94]. Studies have shown that NOB can inhibit the growth of TNBC's MDA-MB-468 cells by inhibiting the AKT-mTOR pathway [94]. Furthermore, NOB can significantly reduce MCF-7 cell viability and inhibit cell growth in a dose-dependent manner [88]. The reason is that $\mathrm{NOB}$ induces its metabolism by upregulating cytochrome P450-1A1 (CYP1A1) and cytochrome P4501B1 (CYP1B1), thereby enhancing its cytostatic effect in MCF-7 BC cells [90]. Experiments have proved that NOB reduces the number of Hs578T cells [89]. All these indicate that NOB can inhibit the growth of BC cells.

(2) Tumor Cell Proliferation Inhibition. Cell proliferation is regulated by genes. c-Fos and c-Jun form a dimer, forming transcription factor AP-1 [95]. The transcription and protein expression of genes such as AP-1, cyclin D1, and PCNA [96] can promote cell proliferation $[97,98]$. NOB can bind c-Jun competitively to prevent it from forming dimers, inhibit AP1 from entering the nucleus, and then reduce the expression of PCNA and cyclin D1, thereby inhibiting proliferation. This shows that NOB inhibits cell proliferation through the AP-1 signaling pathway [93]. Studies have confirmed that the survival rate and proliferation ability of MCF-7 cells decreased after NOB treatment, and the cell morphology changed from diamond to round [88]. These suggest that NOB can inhibit tumor cell proliferation.

(3) Tumor Cell Cycle Regulation. A variety of experiments and clinical studies have found that cell cycle regulation disorder is one of the characteristics of tumors and suggest that tumorigenesis may be the result of abnormal cycle regulation [89]. The cell cycle regulation mechanism is under the precise regulation of related genes and runs according to certain rules and rhythms, which determines the growth, division, and death of cells. The abnormality of the cycle regulation can lead to the continuous proliferation of cells, which is the biological basis of tumorigenesis.
NOB regulates the cycle differently for different types of BC cells, such as hormone receptor-positive MCF-7, HER2positive SK-BR-3, and triple-negative MDA-MB-468 cells. NOB induces MDA-MB-468 cell cycle arrest in the $G 0 / G 1$ phase by inhibiting ERK1/2 activity [94], and MCF-7 cells also have significant accumulation in the $G 1$ phase, but for SK-BR-3 cells, the proportion of cells in each cell cycle stage did not change significantly. NOB can increase the $G 2 / M$ phase arrest of Hs578T cells by $14.3 \%$ [89]. Cyclin-D1 is a key regulator of the $G 0 / G 1$ cell cycle checkpoint. NOB inhibits the $G 0 / G 1$ cell cycle by reducing the expression of cyclin-D1 and simultaneously upregulating p21 [94].

(4) Tumor Cell Apoptosis Induction. In multicellular organisms, the balance between cell death and growth is very important for the development and maintenance of body functions. Disorders of balance can lead to the progression of cancer. Therefore, the balance must be strictly controlled, and the presence of interference can be eliminated through a process called programmed cell death [99]. Apoptosis occurs in two main ways: one is the exogenous way and the other is the endogenous way. The external pathway is through ligand binding to activate the death receptor leading to the activation of caspase-8, while the internal pathway is through the mitochondrial pathway [99].

Studies have shown that the cells after NOB treatment have apoptotic morphological changes in the nucleus, including apoptotic bodies and nuclear condensation [88]. NOB can activate Bax (proapoptotic effect) in MCF7 cells, then increase the permeability of the outer mitochondrial membrane, and release cytochrome C (Cyt-c) from the mitochondria into the cytoplasm, leading to the activation of the apoptotic complex [100]. On the contrary, NOB can inhibit Bcl-2, which has the effect of inhibiting apoptosis [101]. After Bcl-2 is reduced, the intracellular cascade activity is activated, leading to cell apoptosis [102, 103]. In addition, NOB increases the phosphorylation of p38 and reduces the transport of p65 and Nrf2 to the nucleus [88]. This shows that NOB can induce BC cell apoptosis from multiple angles and pathways.

(5) Migration and Invasion Inhibition. Metastasis of the tumor involves local invasion and blood diffusion. The adhesion between tumor cells mediated by cell adhesion molecules is reduced. Tumor cells adhere closely to the basement membrane and secrete proteolytic enzymes to degrade the extracellular matrix, causing local defects in the basement membrane. After the cancer cells move through the dissolving basement membrane defect with amoeba, they continue to dissolve the interstitial connective tissue and move in the interstitium. When they reach the blood vessel wall, they pass through the basement membrane of the blood vessel and enter the blood vessel in the same way, forming the new metastases eventually [104].

MMPs participate in the degradation of the basement membrane and are a necessary process for migration [104]. NOB can downregulate the protein expression of MMP-2 and MMP-9 at the transcription and translation levels and 


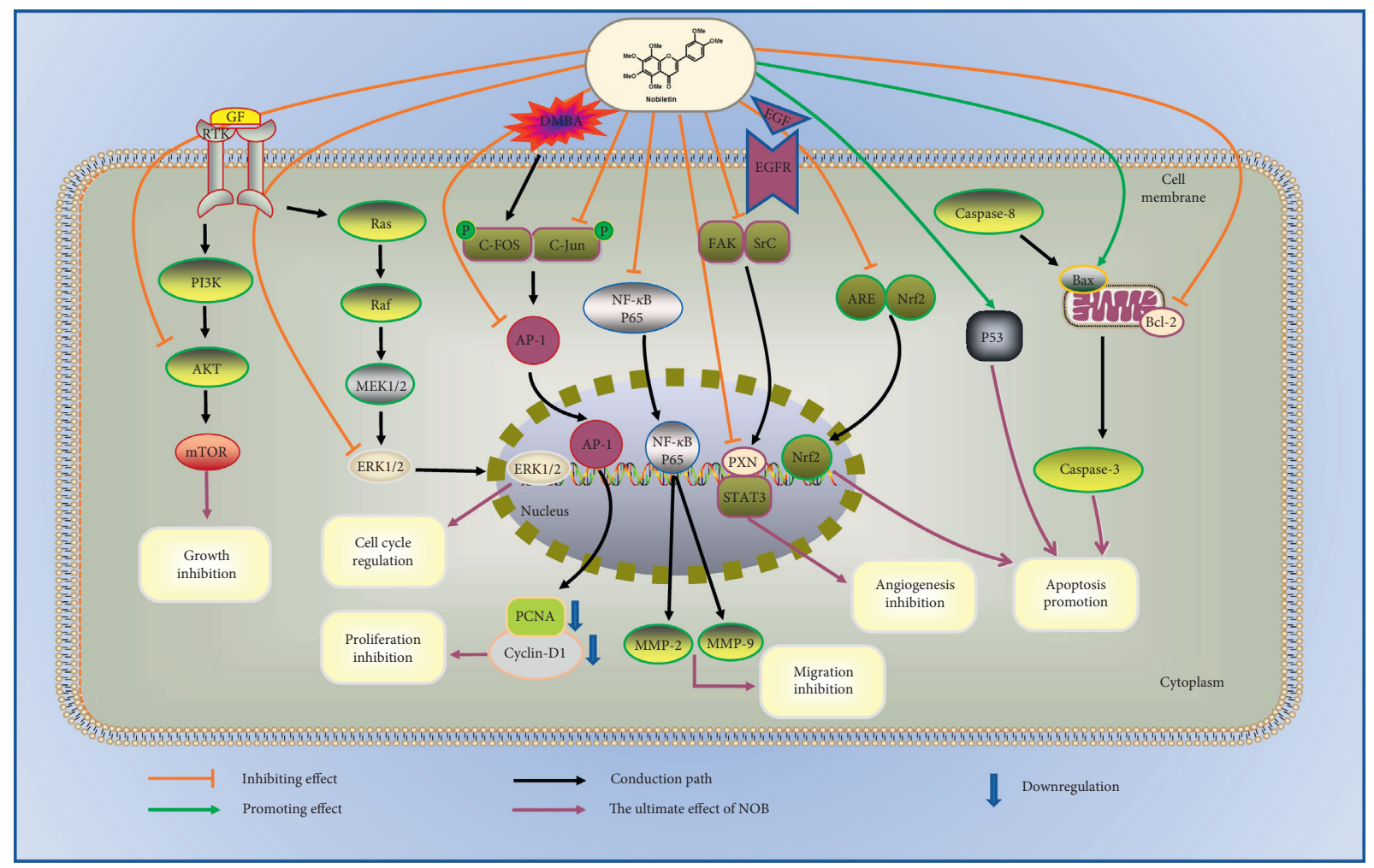

FIgURE 3: The antitumor mechanism of NOB in BC.

then inhibit cell migration [88]. Moreover, NOB can change the morphology of MCF-7 cells, making them to shrink and weakening their adhesion [88]. The results of the scratch test on MCF-7 cells showed that the inhibitory effect of NOB on the stenosis of the defect area was dose dependent [88]. Borah et al. also proved that NOB significantly reduces the migration rate of $\mathrm{Hs} 578 \mathrm{~T}$ cells [89]. And $\mathrm{NOB}$ also reduces the invasion behavior of MDA-MB-231 cells [38]. These experiments showed that $\mathrm{NOB}$ can inhibit the migration and invasion of a variety of $\mathrm{BC}$ cells.

(6) Angiogenesis Inhibition. Tumor angiogenesis is considered to be a key sign of tumor progression. The formation of new blood vessels is to make up for the lack of blood supply and provide sufficient oxygen for tumor progression [105]. Vascular endothelial growth factor (VEGF) is the main growth factor in tumor angiogenesis, while NOB can inhibit angiogenesis by inhibiting VEGF. NOB can also directly dock with the ATP-binding site of EGFR, which has an inhibitory effect. NOB can competitively bind to the site (GAS element, ttctgggaa) where STAT3 initiates transcription, to inhibit the expression level of the STAT3/PXN complex, thereby inhibiting angiogenesis at the transcriptional level [91].

In short, NOB plays a certain role in the BC treatment in many aspects, such as inhibition of tumor cell growth and proliferation, regulation of the tumor cell cycle, induction of tumor cell apoptosis, inhibition of migration and invasion, and inhibition of angiogenesis. However, most of the experiments are in vitro; perhaps, we could confirm its effects in vivo in the future.

\subsubsection{NOB Reducing Chemotherapeutic Drugs' Toxicity and Reversing $M D R$}

(1) Reducing the Toxicity of Chemotherapeutic Drugs. NOB can improve the efficacy of chemotherapeutic drugs and reduce the dosage [106]. For example, doxorubicin is a commonly used chemotherapy drug in the BC treatment. This drug's use effect is low, and it is easy to produce toxic to normal tissues [107]. Studies have shown that NOB can not only increase the cytotoxic activity of doxorubicin on MCF-7 cells but also inhibit the overexpression of adhesion molecules in vascular endothelial cells caused by doxorubicin, thereby reducing cardiotoxicity [106]. NOB also increased the chemotherapeutic sensitivity of BC cell MDA-MB-231 to epirubicin by regulating PER2. It shows that NOB can not only reduce the toxicity of chemotherapy drugs but also increase the effect of chemotherapy drugs.

(2) Reversing Multidrug Resistance. The mechanisms of MDR are the overexpression of ATP-binding cassette (ABC) membrane transporters, especially P-gp, which is considered to be the main factor.

Scientists found that NOB not only increased the accumulation of chemotherapy drugs in ABCB1-overexpressed cancer cells by inhibiting p-gp but also inhibited the Nrf2/ Akt/ERK pathway, thereby enhancing the anticancer effect of paclitaxel in drug-resistant cancer cells [108]. NOB can also reverse drug resistance of PTX in MDR tumors by inhibiting the Akt/ERK/NRF2 pathway [109]. Therefore, NOB can enhance chemotherapy drugs' effects by alleviating MDR. 
TABLE 3: The antitumor activity of NOB in BC.

\begin{tabular}{|c|c|c|c|c|c|}
\hline Mechanism & Cell lines/animal models & $\begin{array}{c}\text { In } \\
\text { vitro/ } \\
\text { in vivo } \\
\end{array}$ & Assay/treatment & Results & References \\
\hline $\begin{array}{l}\text { Cell viability } \\
\text { inhibition }\end{array}$ & $\begin{array}{l}1 \mathrm{MCF}-7 \text { cell } \\
2 \mathrm{Hs} 578 \mathrm{~T} \text { cells }\end{array}$ & $\begin{array}{l}\text { In } \\
\text { vitro }\end{array}$ & An MTT assay & $\begin{array}{l}\text { (i) At } 12.5 \mu \mathrm{M}, \mathrm{NOB} \text { decreased the cell } \\
\text { viability to } 85.3 \pm 4.5 \% \\
\text { At } 25 \mu \mathrm{M}, \mathrm{NOB} \text { decreased the cell } \\
\text { viability to } 79.3 \pm 7.0 \% \\
\text { At } 50 \mu \mathrm{M}, \mathrm{NOB} \text { decreased the cell } \\
\text { viability to } 71.2 \pm 5.0 \% \\
\text { At } 100 \mu \mathrm{M}, \mathrm{NOB} \text { decreased the cell } \\
\text { viability to } 60.3 \pm 6.0 \% \\
\text { At } 200 \mu \mathrm{M}, \mathrm{NOB} \text { decreased the cell } \\
\text { viability to } 54.4 \pm 4.5 \% \\
\text { (ii) At } 100 \mu \mathrm{M}, \mathrm{NOB} \text { showed greater } \\
\text { toxicity toward the more invasive } \\
\text { Hs578Ts(i) } 8 \text { variant cell line, } \\
\text { decreasing the cell viability to } 51.6 \% \\
\text { after } 72 \mathrm{~h}\end{array}$ & $\begin{array}{l}{[88]} \\
{[89]}\end{array}$ \\
\hline $\begin{array}{l}\text { Cell growth } \\
\text { inhibition }\end{array}$ & Hs578T cells & $\begin{array}{c}\text { In } \\
\text { vitro }\end{array}$ & Cell counting & $\begin{array}{l}\text { After } 24 \mathrm{~h} \text {, limited effects were } \\
\text { observed } \\
\text { After } 48 \mathrm{~h}, \mathrm{NOB} \text { reduced the number } \\
\text { of cells by } 40 \% \\
\text { After } 72 \mathrm{~h}, \mathrm{NOB} \text { reduced the number } \\
\text { of cells by } 50 \%\end{array}$ & [89] \\
\hline Cell cycle arrest & Hs578T cells & $\begin{array}{l}\text { In } \\
\text { vitro }\end{array}$ & Western blot assay & $\begin{array}{l}\text { Chk2 phosphorylation at T } 68 \\
\text { decreased after } 10 \text { min in the presence } \\
\text { of NOB }\end{array}$ & [89] \\
\hline Cell cycle arrest & MCF-7 cells & $\begin{array}{l}\text { In } \\
\text { vitro }\end{array}$ & Flow cytometry assay & $\begin{array}{l}\text { At } 100 \mu \mathrm{M} \text { of NOB, a } G 1 \text { block } \\
\text { occurred in MCF- } 7 \text { cells that was } \\
\text { accompanied }\end{array}$ & {$[90]$} \\
\hline $\begin{array}{l}\text { Proliferation } \\
\text { inhibition }\end{array}$ & $\begin{array}{c}\text { MCF-7, T47D, MDA-MB- } \\
\text { 231c }\end{array}$ & $\begin{array}{l}\text { In } \\
\text { vitro }\end{array}$ & An MTT assay & $\begin{array}{l}\text { NOB had a strong inhibitory effect on } \\
\text { the proliferation of MDA-MB- } 231 \\
\text { cells and a weak inhibitory effect on } \\
\text { the proliferation of HUVEC cells }\end{array}$ & {$[91]$} \\
\hline $\begin{array}{l}\text { Proliferation } \\
\text { inhibition }\end{array}$ & MDA-MB-435, MCF-7 & $\begin{array}{c}\text { In } \\
\text { vitro }\end{array}$ & Cell counting & $\begin{array}{l}\text { Inhibition rates of NOB on treated } \\
\text { cells ranged from } 60 \text { to } 95 \% \text {, beginning } \\
\text { at } 12 \mathrm{~h} \text { and lasting up to } 4 \text { days, in all } \\
\text { cell lines }\end{array}$ & {$[92]$} \\
\hline
\end{tabular}

(i) Compared with normal rats, the expression of proliferation-related

Breast cancer model

Proliferation inhibition

(i) Adult female Sprague

Dawley rats with body

weights (BWs) of

180-220 g (6-7 weeks old)
In vivo DMBA (control rats)

NOB (experimental rats) proteins was increased in DMBAtreated rats

(ii) NOB-treated rats showed downregulation of cell proliferation protein expression

(iii) No significant changes were observed in the normal control group and rats treated with $\mathrm{NOB}$ alone

At $50 \mu \mathrm{M}$, NOB induced cell apoptosis at the rates of $8.62 \pm 3.5 \%$ At $100 \mu \mathrm{M}$, NOB induced cell

Apoptosis promotion
MCF-7 cells
In vitro
Flow cytometry assay apoptosis at the rates of $11.2 \pm 2.0 \%$

At $200 \mu \mathrm{M}$, NOB induced cell

apoptosis at the rates of $17.1 \pm 3.7 \%$

The apoptosis rate of untreated cells was $5.4 \pm 0.97 \%$ 
TABle 3: Continued.

Mechanism Cell lines/animal models $\begin{gathered}\text { In } \\ \text { vitro/ } \\ \text { in vivo }\end{gathered} \quad$ Assay/treatment $\quad$ Results

(i) At $200 \mu \mathrm{M}$ of NOB, the inhibition rates of the migration were $38.2 \pm 3.2 \%$ after $24 \mathrm{~h}$

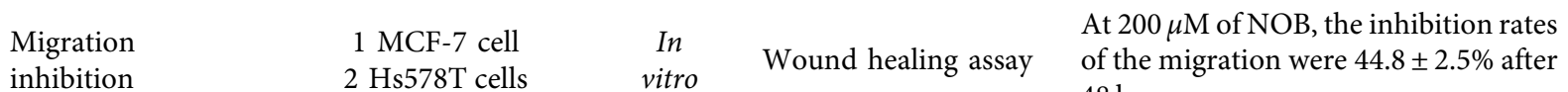
$48 \mathrm{~h}$

(ii) At $100 \mu \mathrm{M}$ of $\mathrm{NOB}$, the migration was reduced by $40 \%$ in the Hs578Ts(i) 8 cell

\begin{tabular}{|c|c|c|c|c|c|}
\hline $\begin{array}{l}\text { Migration } \\
\text { inhibition }\end{array}$ & MCF-7 cells & $\begin{array}{c}\text { In } \\
\text { vitro }\end{array}$ & Western blot assay & $\begin{array}{l}\text { The expression levels of MMP- } 2 \text { and } \\
\text { MMP-9 were decreased in MCF- } 7 \text { cell } \\
\text { lines }\end{array}$ & [88] \\
\hline
\end{tabular}

(i) At 50, 100, and $200 \mu \mathrm{M}, \mathrm{NOB}$ downregulated the translocation of p65 in the MCF-7 cells

(ii) NOB had no significant effect on p65 protein expression at this

Western blot and quantified protein levels

Expression of protein connected MCF-7 cells with $\mathrm{BC}$ of total p65 and nuclear p65 p38 and p-p38 Total Nrf2 and nuclear Nrf2 concentration (iii) At 100 and $200 \mu \mathrm{M}$ of NOB, the level of p-p38 was significantly increased

At $50 \mu \mathrm{M}$, NOB had no significant effect on $\mathrm{p} 38$ phosphorylation At 100 and $200 \mu \mathrm{M}$, NOB significantly affected the expression of $\mathrm{p} 38$ (iv) At 100 and $200 \mu \mathrm{M}$, NOB significantly reduced the levels of $\mathrm{Nrf} 2$ At $50 \mu \mathrm{M}$, NOB had no obvious effect

At $200 \mu \mathrm{M}$, NOB significantly inhibited tube formation in the extracellular matrix At $200 \mu \mathrm{M}$ of NOB, the inhibition of angiogenesis occurred in HUVEC cells (i) NOB downregulated the expression

Angiogenesis assay Western blot assay RT-PCR analysis Electrophoretic mobility shift assay (EMSA) of phosphorylated EGFR

(ii) NOB reduced the expression levels of phosphorylated Src, FAK, STAT3, and PXN

(iii) After NOB treatment for $24 \mathrm{~h}$, angiogenic factors were inhibited (iv) NOB downregulated the DNA/ STAT3 complex in MCF-7 and T47D cells
3.3.4. Pharmacodynamics and Pharmacokinetics of NOB. Recently, some reports have proposed that NOB is absorbed by proton-linked carboxylic acid transporters in the intestinal tract of Caco- 2 cells [110]. Caco- 2 cells are similar in morphology and function to small intestinal epithelial cells and are widely used to study in vitro models of drug absorption. The results show that the absorption of NOB is saturated at low concentration and unsaturated at high concentration [111]. The absorption of NOB by Caco- 2 cells is mainly mediated by passive diffusion [111].

Studies have shown that NOB significantly accumulates in the blood, urine, stomach, small intestine, liver, and kidney within 1 to 4 hours of administration. In addition, a large amount of NOB remained in the gastric muscle layer 1 hour after administration, indicating that NOB may enter the circulation through the gastric muscle layer [112], probably due to the high hydrophobicity of NOB [113].

After oral intake, NOB further forms a variety of metabolites [114]. NOB generally undergoes phase I and phase II metabolism, and more than 16 metabolites have been identified so far [115]. After NOB is metabolized by mice, the three common phase I metabolites in urine are $3^{\prime}$-DMN, $4^{\prime}$ DMN, and $3^{\prime}, 4^{\prime}-\mathrm{DMN}$ [116]. According to some reports, the metabolism of flavonoids in animals is carried out by hydroxylation and oxidative demethylation of cytochrome p450 [117]. Furthermore, in vivo experiments have shown 
that the phase I demethylation of NOB is caused by cytochrome P450. Researchers found that CYP1A1, CYP1A2, and CYP1B1 have high activity in the formation of $3^{\prime}-\mathrm{DMN}$, confirming that these enzymes are involved in the metabolism of NOB [118].

NOB undergoes phase II metabolism in the small intestine [119]. Phase II metabolites contain glucuronic and sulfonic conjugates in the serum, bile, and urine of rats [119]. The unabsorbed compounds in the small intestine will enter the large intestine. After being decomposed by the intestinal microorganisms, some of them will be reingested, and the others will enter blood [120].

The intestinal efflux transporter (P-gp), which is widely distributed in the mucosa of intestinal epithelial cells, can pump the absorbed NOB out of the cell membrane and return to the intestinal lumen; it can also cooperate with metabolic enzymes to prevent the absorption of NOB. Eventually, NOB is excreted through urine or feces [121].

$\mathrm{NOB}$ has been reported to be a safe agent for in vivo use as it has not caused any long-term toxicity or significant weight and liver weight reduction, which are the signs of toxicity $[27,93,122,123]$. Because of the existence of a large number of methoxy groups and high hydrophobicity, NOB has poor water solubility (less than $1 \mu \mathrm{g}$ / $\mathrm{ml}$ ) and low bioavailability [124]. And it is easy to crystallize in the human body at room temperature and is difficult to absorb [125]. Therefore, to improve its bioavailability, researchers have used ASDs (amorphous solid dispersions) to improve the solubility and gastrointestinal absorption of NOB to maintain drug concentration by increasing dissolution rate and preventing recrystallization [126]. And nanotechnology can be used to give NOB chemical stability to improve its bioavailability and therapeutic effect [127].

\section{Discussion}

Most of the current studies are that NOB directly acts on tumor cells. The mechanisms contain inhibiting cell growth and proliferation, regulating the cell cycle, promoting cell apoptosis, and inhibiting migration and invasion from the level of genes, transcription, and translation. However, the effects of NOB on metabolism, immune cells, intercellular substances, and tumor microenvironment need to be further studied. Most of the experiments of NOB are cell experiments, and there is only one in vivo. Since the tumor microenvironment is relatively complex, experiments in vivo are more accurate and convincing. In the future, it is necessary to further study whether the role of $\mathrm{NOB}$ in vivo is consistent with that in vitro and whether there is any interaction with other tissues. In addition to nude mice, other animal models can be tried, such as immune survivable mice and zebrafish. Zebrafish is also a well-developed ideal in vivo model. For metastatic TNBC, it can simulate the process of metastasis in a short period of time, and the detection is relatively simple. In addition, there are relatively few studies on NOB combined with chemotherapy and targeted drugs in the treatment of BC. Experiments should be carried out to observe the effects of NOB combined with other treatments.
NOB is highly fat-soluble, while traditional Chinese medicine decoctions are mostly water decoctions. The possible reason is the dosage of Citrus folium or the compatibility of CM having an impact on its efficacy or other ingredients in Citrus folium making effects, which needs further study. The bioavailability of NOB is low. To increase the bioavailability, we can try to change the dosage form, such as intravenous administration, or make structural modifications or change the biological activity of NOB through nanoadsorbed drugs. The biological activities of the metabolites of NOB entering the body, $3^{\prime}$-DMN, $4^{\prime}$-DMN, and $3^{\prime}, 4^{\prime}$-DMN, are also worth exploring. Different effects of Citrus folium on different targets of ER, PR, and HER2 also require clinical research studies.

Discovering the antitumor mechanism of NOB has realized the research from clinical to basic and then from basic to clinical, which has certain potential value. From a molecular perspective, compared with other cell lines, NOB shows more cell proliferation inhibitory effects on the TNBC cell line MDA-MB-231, indicating that NOB may be more effective on TNBC. From the perspective of TCM syndrome differentiation, receptor-positive patients are usually treated with endocrine drugs and are mostly of Yin deficiency and heat, while TNBC patients are mostly of qi stagnation and blood stasis type. Citrus folium enters the liver meridian, which has the effect of regulating qi and dispelling stagnation. It may be more effective for TNBC patients. In summary, it is possible to further screen the more effective syndromes of NOB treatment, with a view to the more precise treatment of different types of BC.

\section{Conclusion}

A majority of studies focusing on the anticancer effects of Citrus folium and its main active ingredients have been carried out and identified in the past ten years. Although the clinical application of Citrus folium in TCM has a long history, its specific mechanism deserves further exploration, such as its role in multiple system diseases and its future application as an anticancer molecular target. The precise molecular action of each identified compound and biological activities of multicompounds remains to be elucidated. Therefore, it is necessary to study the effects of Citrus folium and NOB in vivo through a variety of applications, such as topical, oral, or injection. Further research warrants investigation into the effect of Citrus folium and its active components on the tumor-related immune functions, cancer stem cells, and the tumor microenvironment to provide more throughout picture of its action mechanism for cancer therapies.
Abbreviations
NOB: Nobiletin
IARC: The International Agency for Research on Cancer
BC: $\quad$ Breast cancer
TNBC: $\quad$ Triple-negative breast cancer
EMT: Epithelial-mesenchymal transition 


$\begin{array}{ll}\text { CNKI: } & \text { China National Knowledge Infrastructure } \\ \text { UPLC: } & \begin{array}{l}\text { Ultrahigh-performance liquid } \\ \text { chromatography }\end{array} \\ \text { LC-ESI-MS/ } & \text { Lipid chromatography combined with } \\ \text { MS: } & \text { electrospray mass spectrometry } \\ \text { PMFs: } & \text { Polymethoxyflavones } \\ \text { IUPAC: } & \text { International Union of Pure and Applied } \\ & \text { Chemistry } \\ \text { 5-DMN: } & \text { 5-Demethylnobiletin } \\ \text { TCM: } & \text { Traditional Chinese medicine } \\ \text { ROS: } & \text { Reactive oxygen species } \\ \text { ER: } & \text { Estrogen receptor } \\ \text { PR: } & \text { Progesterone receptor } \\ \text { MTT: } & \text { 3-(4,5-Dimethylthiazol-2)-2,5- } \\ & \text { diphenyltetrazolium bromide } \\ \text { CYP1A1: } & \text { Cytochrome P4501A1 } \\ \text { CYP1B1: } & \text { Cytochrome P4501B1 } \\ \text { MAPK: } & \text { Mitogen-activated protein kinases } \\ \text { CXCR4: } & \text { Chemokine (C-X-C motif) receptor } 4 \\ \text { IC50: } & \text { Half-maximal inhibitory concentration } \\ \text { ASD: } & \text { Amorphous solid dispersion } \\ \text { Ras: } & \text { GTP-binding protein } \\ \text { Raf: } & \text { Serine-threonine protein kinase } \\ \text { MEK: } & \text { Mitogen-activated protein kinase kinase } \\ \text { ERK1/2: } & \text { Extracellular signal-regulated kinases } \\ \text { RTK: } & \text { Receptor tyrosine kinase } \\ \text { GF: } & \text { Growth factor } \\ \text { PI3K: } & \text { Phosphoinositide 3-kinases } \\ \text { AKT: } & \text { Protein kinase B } \\ \text { mTOR: } & \text { Mammalian target of rapamycin } \\ \text { DMBA: } & \text { 7,12-Dimethylbenz[a]anthracene } \\ \text { AP-1: } & \text { Activator protein-1 } \\ \text { PCNA: } & \text { Proliferative cell nuclear antigen } \\ \text { NF- } \kappa \text { B: } & \text { Nuclear factor kappa-B } \\ \text { MMP-2: } & \text { Matrix metallopeptidase-2 } \\ \text { MMP-9: } & \text { Matrix metallopeptidase- } 9 \\ \text { EGF: } & \text { Epidermal growth factor } \\ \text { EGFR: } & \text { Epidermal growth factor receptor } \\ \text { FAK: } & \text { Focal adhesion kinase } \\ \text { Src: } & \text { Steroid receptor coactivator } \\ \text { STAT3: } & \text { Signal transducer and activator of } \\ & \text { transcription } 3 \\ \text { PXN: } & \text { Paxillin, a focal adhesion-related protein } \\ \text { Nrf2: } & \text { Nuclear factor erythroid 2-related factor } 2 \\ \text { Bcl-2: } & \text { B-cell lymphoma 2 protein. } \\ & \end{array}$

\section{Disclosure}

All authors agreed to be accountable for all aspects of the work.

\section{Conflicts of Interest}

The authors declare no conflicts of interest.

\section{Authors' Contributions}

L. Z., C.-S. C., and J.-X. C. were responsible for conceptualization. Y. W. participated in the writing of the original manuscript. Y. W. and J.-S. C. conducted an analysis. L.-L. L. and Q. L. were responsible for verification. Y. W., J.-X. C., J.-Y. X., J.-X. C., and K.-Y. Z. reviewed and edited the article. L.-L. L. and L. Z. were responsible for the visualization. L. Z. oversaw and raised the funding. All authors assisted in revising the paper.

\section{Acknowledgments}

This work was supported by grants from the Staged Intervention of Triple-Negative Breast Cancer with "Adjusting and Reinforcing Liver and Kidney Therapy" and the Discussion on the Immune Correlation (no. 19401932400).

\section{References}

[1] J. Wagner, M. A. Rapsomaniki, S. Chevrier et al., "A singlecell atlas of the tumor and immune ecosystem of human breast cancer," Cell, vol. 177, no. 5, pp. 1330-1345, 2019.

[2] C. Woolston, "Breast cancer," Nature, vol. 527, no. 7578, p. S101, 2015.

[3] M. A. Franzoi, E. Romano, and M. Piccart, "Immunotherapy for early breast cancer: too soon, too superficial, or just right?" Annals of Oncology, vol. 32, no. 3, pp. 323-336, 2021.

[4] C. Yam, R. K. Murthy, V. Valero et al., "A phase II study of tipifarnib and gemcitabine in metastatic breast cancer," Investigational New Drugs, vol. 36, no. 2, pp. 299-306, 2018.

[5] X. Jiang, N. L. Dimou, N. L. Dimou et al., "Allergy, asthma, and the risk of breast and prostate cancer: a Mendelian randomization study," Cancer Causes \& Control, vol. 31, no. 3, pp. 273-282, 2020.

[6] S. Dharmaiah, J. Zeng, V. S. Rao et al., "Clinical and dosimetric evaluation of recurrent breast cancer patients treated with hyperthermia and radiation," International Journal of Hyperthermia, vol. 36, no. 1, p. 1072, 2019.

[7] Y. Naito, Y. Kai, T. Ishikawa et al., "Chemotherapy-induced nausea and vomiting in patients with breast cancer: a prospective cohort study," Breast Cancer, vol. 27, no. 1, pp. 122-128, 2020.

[8] M. Barok, H. Joensuu, and J. Isola, "Trastuzumab emtansine: mechanisms of action and drug resistance," Breast Cancer Research, vol. 16, no. 2, 2014.

[9] K.-H. Chun, J. H. Park, and S. Fan, "Predicting and overcoming chemotherapeutic resistance in breast cancer," Advances in Experimental Medicine and Biology, vol. 1026, pp. 59-104, 2017.

[10] A. Demichele, D. Yee, and L. Esserman, "Mechanisms of resistance to neoadjuvant chemotherapy in breast cancer," New England Journal of Medicine, vol. 377, no. 23, pp. 2287-2289, 2017.

[11] I. Cohen, M. Tagliaferri, and D. Tripathy, "Traditional Chinese medicine in the treatment of breast cancer," Seminars in Oncology, vol. 29, no. 6, pp. 563-574, 2002.

[12] W.-W. Tao, H. Jiang, X.-M. Tao, P. Jiang, L.-Y. Sha, and X.-C. Sun, "Effects of acupuncture, Tuina, Tai Chi, Qigong, and traditional Chinese medicine five-element music therapy on symptom management and quality of life for cancer patients: a meta-analysis," Journal of Pain and Symptom Management, vol. 51, no. 4, pp. 728-747, 2016.

[13] Z. Yang, Q. Zhang, L. Yu, J. Zhu, Y. Cao, and X. Gao, “The signaling pathways and targets of traditional Chinese medicine and natural medicine in triple-negative breast 
cancer," Journal of Ethnopharmacology, vol. 264, Article ID 113249, 2021.

[14] K. Wang, Q. Chen, Y. Shao et al., "Anticancer activities of TCM and their active components against tumor metastasis," Biomedicine \& Pharmacotherapy, vol. 133, Article ID 111044, 2021.

[15] C. L. Poo, H. D. Dewadas, F. L. Ng et al., "Effect of traditional Chinese medicine on musculoskeletal symptoms in breast cancer: a systematic review and meta-analysis," Journal of Pain and Symptom Management, 2020.

[16] N. H. Oberlies and D. J. Kroll, "Camptothecin and Taxol: historic achievements in natural products research," Journal of Natural Products, vol. 67, no. 2, pp. 129-135, 2004.

[17] Y. Lu, C.-S. Li, and Q. Dong, "Chinese herb related molecules of cancer-cell-apoptosis: a minireview of progress between Kanglaite injection and related genes," Journal of Experimental \& Clinical Cancer Research, vol. 27, no. 1, p. 31, 2008.

[18] F. Qi, A. Li, Y. Inagaki et al., "Antitumor activity of extracts and compounds from the skin of the toad Bufo bufo gargarizans Cantor," International Immunopharmacology, vol. 11, no. 3, pp. 342-349, 2011.

[19] Y. Wang, "Basic, clinical, \& medicine," China Standardization, vol. 4, no. 73, pp. 132-135, 2015.

[20] F. Dong, G. Rao, and H. E. Hp, "Isolation and identification of chemical constituents from orange leaves," Chinese Journal of Experimental Formulae, vol. 24, no. 21, pp. 46-50, 2018.

[21] N. Yoshizaki, R. Hashizume, and H. Masaki, "A polymethoxyflavone mixture extracted from orange peels, mainly containing nobiletin, 3,3', $4^{\prime}, 5,6,7,8$-heptamethoxyflavone and tangeretin, suppresses melanogenesis through the acidification of cell organelles, including melanosomes," Journal of Dermatological Science, vol. 88, no. 1, pp. 78-84, 2017.

[22] E. Mileykovskaya, S. H. Yoo, W. Dowhan et al., "Nobiletin: targeting the circadian network to promote bioenergetics and healthy aging," Biochemistry, vol. 85, no. 12, pp. 1554-1559, 2020.

[23] G. Yang, C.-C. Lin, Y. Yang et al., "Nobiletin prevents Trimethylamine oxide-induced vascular inflammation via inhibition of the NF- $\kappa$ B/MAPK pathways," Journal of Agricultural and Food Chemistry, vol. 67, no. 22, pp. 6169-6176, 2019.

[24] Y. Xiong, D. Chen, C. Yu et al., "Citrus nobiletin ameliorates experimental colitis by reducing inflammation and restoring impaired intestinal barrier function," Molecular Nutrition \& Food Research, vol. 59, no. 5, pp. 829-842, 2015.

[25] Y. Hagenlocher, S. Gommeringer, A. Held et al., "Nobiletin acts anti-inflammatory on murine IL-10-/- colitis and human intestinal fibroblasts," European Journal of Nutrition, vol. 58, no. 4, pp. 1391-1401, 2019.

[26] Z. Hu, J. Hu, F. Ren et al., "Nobiletin, a novel inhibitor, inhibits HBsAg production and hepatitis B virus replication," Biochemical and Biophysical Research Communications, vol. 523, no. 3, pp. 802-808, 2020.

[27] S.-C. Lin, M.-C. Chen, S. Li, C.-C. Lin, and T. T. Wang, "Antiviral activity of nobiletin against chikungunya virus in vitro," Antiviral Therapy, vol. 22, no. 8, pp. 689-697, 2017.

[28] W.-J. Lu, K.-C. Lin, C.-P. Liu et al., "Prevention of arterial thrombosis by nobiletin: in vitro and in vivo studies," The Journal of Nutritional Biochemistry, vol. 28, pp. 1-8, 2016.

[29] K. Amarsanaa, H.-J. Kim, E.-A. Ko, J. Jo, and S.-C. Jung, "Nobiletin exhibits neuroprotective effects against mitochondrial complex I inhibition via regulating apoptotic signaling," Experimental Neurobiology, vol. 30, no. 1, pp. 73-86, 2021.

[30] J. H. Lee, K. Amarsanaa, J. Wu et al., "Nobiletin attenuates neurotoxic mitochondrial calcium overload through $\mathrm{K}+$ influx and $\Delta \Psi \mathrm{m}$ across mitochondrial inner membrane," The Korean Journal of Physiology \& Pharmacology, vol. 22, no. 3, pp. 311-319, 2018.

[31] Y. Qu, Y. Liu, L. Chen et al., "Nobiletin prevents cadmiuminduced neuronal apoptosis by inhibiting reactive oxygen species and modulating JNK/ERK1/2 and Akt/mTOR networks in rats," Neurological Research, vol. 40, no. 3, pp. 211-220, 2018.

[32] A. Nakajima and Y. Ohizumi, "Potential benefits of nobiletin, A citrus flavonoid, against Alzheimer's disease and Parkinson's disease," International Journal of Molecular Sciences, vol. 20, no. 14, 2019.

[33] A. Nakajima, Y. Ohizumi, and K. Yamada, "Anti-dementia activity of nobiletin, a citrus flavonoid: a review of animal studies," Clinical Psychopharmacology and Neuroscience, vol. 12, no. 2, pp. 75-82, 2014.

[34] T. Wang, F. Wang, L. Yu et al., "Nobiletin alleviates cerebral ischemic-reperfusion injury via MAPK signaling pathway," American Journal of Translational Research, vol. 11, no. 9, pp. 5967-5977, 2019.

[35] B. Liu, Q. Deng, L. Zhang, and W. Zhu, "Nobiletin alleviates ischemia/reperfusion injury in the kidney by activating PI3K/AKT pathway," Molecular Medicine Reports, vol. 22, no. 6, pp. 4655-4662, 2020.

[36] G. Qi, R. Guo, H. Tian et al., "Nobiletin protects against insulin resistance and disorders of lipid metabolism by reprogramming of circadian clock in hepatocytes," Biochimica et Biophysica Acta (BBA)-Molecular and Cell Biology of Lipids, vol. 1863, no. 6, pp. 549-562, 2018.

[37] S.-Y. Chien, M.-J. Hsieh, C.-J. Chen, S.-F. Yang, and M.-K. Chen, "Nobiletin inhibits invasion and migration of human nasopharyngeal carcinoma cell lines by involving ERK1/2 and transcriptional inhibition of MMP-2," Expert Opinion on Therapeutic Targets, vol. 19, no. 3, pp. 307-320, 2015.

[38] S. H. Baek, S.-M. Kim, D. Nam et al., "Antimetastatic effect of nobiletin through the down-regulation of CXC chemokine receptor type 4 and matrix metallopeptidase-9," Pharmaceutical Biology, vol. 50, no. 10, pp. 1210-1218, 2012.

[39] C. Da, Y. Liu, Y. Zhan et al., "Nobiletin inhibits epithelialmesenchymal transition of human non-small cell lung cancer cells by antagonizing the TGF-beta1/Smad3 signaling pathway," Oncology Reports, vol. 35, no. 5, pp. 2767-2774, 2016.

[40] J. Y. Moon, M. Cho, K. S. Ahn, and S. K. Cho, "Nobiletin induces apoptosis and potentiates the effects of the anticancer drug 5-fluorouracil in p53-mutated SNU-16 human gastric cancer cells," Nutrition and Cancer, vol. 65, no. 2, pp. 286-295, 2013.

[41] X. Wu, M. Song, M. Wang et al., "Chemopreventive effects of nobiletin and its colonic metabolites on colon carcinogenesis," Molecular Nutrition \& Food Research, vol. 59, no. 12, pp. 2383-2394, 2015.

[42] X. Ma, S. Jin, Y. Zhang, L. Wan, Y. Zhao, and L. Zhou, "Inhibitory effects of nobiletin on hepatocellular carcinoma in vitro and in vivo," Phytotherapy Research, vol. 28 , no. 4, pp. 560-567, 2014.

[43] J. Chen, A. Creed, A. Y. Chen et al., "Nobiletin suppresses cell viability through AKT Pathways in PC-3 and DU-145 
prostate cancer cells," BMC Pharmacology and Toxicology, vol. 15, no. 1, p. 59, 2014.

[44] D. Wei, G. Zhang, Z. Zhu et al., "Nobiletin inhibits cell viability via the SRC/AKT/STAT3/YY1AP1 pathway in human renal carcinoma cells," Frontiers in Pharmacology, vol. 10, p. 690, 2019.

[45] Y. G. Goan, W. T. Wu, C. I. Liu et al., "Involvement of mitochondrial dysfunction, endoplasmic reticulum stress, and the $\mathrm{PI} 3 \mathrm{~K} / \mathrm{AKT} / \mathrm{mTOR}$ pathway in nobiletin-induced apoptosis of human bladder cancer cells," Molecules, vol. 24, no. 16, 2019.

[46] J. Chen, A. Y. Chen, H. Huang et al., "The flavonoid nobiletin inhibits tumor growth and angiogenesis of ovarian cancers via the Akt pathway," International Journal of Oncology, vol. 46, no. 6, pp. 2629-2638, 2015.

[47] L.-M. Lien, M.-J. Wang, R.-J. Chen et al., "Nobiletin, a polymethoxylated flavone, inhibits glioma cell growth and migration via arresting cell cycle and suppressing MAPK and Akt pathways," Phytotherapy Research, vol. 30, no. 2, pp. 214-221, 2016.

[48] H.-L. Cheng, M.-J. Hsieh, J.-S. Yang et al., "Nobiletin inhibits human osteosarcoma cells metastasis by blocking ERK and JNK-mediated MMPs expression," Oncotarget, vol. 7, no. 23, pp. 35208-35223, 2016.

[49] J. A. Manthey and N. Guthrie, "Antiproliferative activities of citrus flavonoids against six human cancer cell lines," Journal of Agricultural and Food Chemistry, vol. 50, no. 21, pp. 5837-5843, 2002.

[50] F. Liu, S. Zhang, M. Yin, L. Guo, M. Xu, and Y. Wang, "Nobiletin inhibits hypoxia-induced epithelial-mesenchymal transition in renal cell carcinoma cells," Journal of Cellular Biochemistry, vol. 120, no. 2, pp. 2039-2046, 2019.

[51] N. Sp, D. Y. Kang, D. H. Kim et al., "Nobiletin inhibits CD36dependent tumor angiogenesis, migration, invasion, and sphere formation through the Cd36/stat3/nf-kappab signaling axis," Nutrients, vol. 10, no. 6, 2018.

[52] M. J. Page, J. E. Mckenzie, P. M. Bossuyt et al., "The PRISMA 2020 statement: an updated guideline for reporting systematic reviews," Journal of Clinical Epidemiology, vol. 134, pp. 178-189, 2021.

[53] X. Z. H. Fu, A. Zhang, and X. Meng, "Research progress in treating breast cancer with traditional Chinese medicine," Journal of New Chinese Medicine, vol. 50, no. 12, pp. 46-48, 2018.

[54] S. G. Chen, Wai Ke Zheng Zong, Shanghai Science and Technology Press, Shanghai, China, 1989.

[55] Z. D. S. Ni, R. Chen, and S. Yu, Ben Cao Hui Yan, Shanghai publisher of Science and Technology, Shanghai, China, 2005.

[56] L. Z. Lan, D. Lei, X. Chen, and S. Li, "Study on the correlation between TCM syndromes of breast cancer and estrogen progesterone receptor," Yunnan Journal of Traditional Chinese Medicine and Materia Medica, vol. 39, no. 11, pp. 28-30, 2018.

[57] W. Q. Hu, H. Yu, and Y. Wang, "Based on the correlation analysis of TCM syndromes in 100 real world patients with bi-rads grade 4 breast masses," Electronic Journal of Practical Gynecological Endocrinology, vol. 6, no. 9, pp. 171-172, 2019.

[58] Q. Xu and H. Han, "Study on the distribution and combination of TCM syndromes in patients with breast cancer with bone metastasis," Chinese Journal of Information on Traditional Chinese Medicine, vol. 26, no. 11, pp. 22-26, 2019.

[59] J. Sun, H. Meng, L. Yao et al., "Germline mutations in cancer susceptibility genes in a large series of unselected breast cancer patients," Clinical Cancer Research, vol. 23, no. 20, pp. 6113-6119, 2017.

[60] S. Cui, "Intervention strategy of traditional Chinese medicine under the "two-sided" mode of breast cancer," Beijing Traditional Chinese Medicine, vol. 39, no. 10, pp. 1018-1021, 2020.

[61] J. L. Zhang, X. Zhou, and D. Wan, “Professor Wan Donggui's experience in treating triple negative breast cancer from sputum," China Medical Herald, vol. 18, no. 9, pp. 156-159, 2021.

[62] M. A. Boermeester and R. M. Butzelaar, "Interaction between breast cancer, psychosocial stress and the immune response," Nederlands Tijdschrift voor Geneeskunde, vol. 143, no. 16, pp. 838-842, 1999.

[63] W. M. P. Klein and M. E. Stefanek, "Cancer risk elicitation and communication: lessons from the psychology of risk perception," CA: A Cancer Journal for Clinicians, vol. 57, no. 3, pp. 147-167, 2007.

[64] N. X. L. Li, L. H. Cui, M. Liu, T. Wang, and C. C. Li, "A casecontrol study of dietary factors and breast cancer risk," Prevention and Control of Chronic Diseases in China, vol. 22, no. 3, pp. 290-294, 2014.

[65] R. W. Blamey, A. R. M. Wilson, and J. Patnick, "ABC of breast diseases: screening for breast cancer," BMJ, vol. 321, no. 7262, pp. 689-693, 2000.

[66] R. Divella, R. De Luca, I. Abbate, E. Naglieri, and A. Daniele, "Obesity and cancer: the role of adipose tissue and adipocytokines-induced chronic inflammation," Journal of Cancer, vol. 7, no. 15, pp. 2346-2359, 2016.

[67] S. Balaban, R. F. Shearer, L. S. Lee et al., "Adipocyte lipolysis links obesity to breast cancer growth: adipocyte-derived fatty acids drive breast cancer cell proliferation and migration," Cancer \& Metabolism, vol. 5, no. 1, 2017.

[68] J. W. Dou, S. Yang, K. L. Li, Y. Zhi, and Q. Huang, “The correlation between the pathogenesis of breast cancer and the understanding of tumor fat microenvironment was discussed," Lishizhen Medicine and Materia Medica Research, vol. 31, no. 6, pp. 1427-1428, 2020.

[69] R. Caparica, M. Lambertini, and E. De Azambuja, "How i treat metastatic triple-negative breast cancer," ESMO Open, vol. 4, 2019.

[70] L. Steward, L. Conant, F. Gao, and J. A. Margenthaler, "Predictive factors and patterns of recurrence in patients with triple negative breast cancer," Annals of Surgical Oncology, vol. 21, no. 7, pp. 2165-2171, 2014

[71] C. Wilson, H. Brown, and I. Holen, "The endocrine influence on the bone microenvironment in early breast cancer," Endocrine-Related Cancer, vol. 23, no. 12, pp. R567-R576, 2016.

[72] C. Gt, Compendium of Materia Medica, Academy Press, Cambridge, MA, USA, 1992.

[73] T. Ye, Zhu Lin Nv Ke Zheng Zhi, Traditional Chinese Medicine Ancient Books Publishing House, Beijing, China, 2018.

[74] B. Gao, Yang Ke Xin De Ji, People's Medical Publishing House, Beijing, China, 2006.

[75] X. Fang, Qi Xiao Liang Fang, The Commercial Press, Beijing, China, 1959

[76] Z. Feng, Feng Shi Jin Nang, People's Medical Publishing House, Beijing, China, 1998.

[77] S. L. Liu, Y. Xue, and J. Cheng, China Press of Traditional Chinese Medicine, Beijing, China, 2015.

[78] L.-q. Qian, X.-h. Pei, Z.-y. Xu, and C. Wang, "Clinical observation on treatment of hyperplasia of mammary gland by 
Lirukang Granule," Chinese Journal of Integrative Medicine, vol. 13, no. 2, pp. 120-124, 2007.

[79] X. R. Sun and L. L. Lv, "Valuation on clinical efficacy of liverregulating, kidney-tonifying and mass-eliminating Therapy by stage for advanced breast cancer," World Chinese Medicine, vol. 14, no. 1, pp. 115-121, 2019.

[80] A. Altemimi, R. Choudhary, D. G. Watson, and D. A. Lightfoot, "Effects of ultrasonic treatments on the polyphenol and antioxidant content of spinach extracts," Ultrasonics Sonochemistry, vol. 24, pp. 247-255, 2015.

[81] F. Dranca and M. Oroian, "Optimization of ultrasoundassisted extraction of total monomeric anthocyanin (TMA) and total phenolic content (TPC) from eggplant (Solanum melongena L.) peel," Ultrasonics Sonochemistry, vol. 31, pp. 637-646, 2016.

[82] Y. Song, H. Chen, Y. Hu, S. Tan, and W. Yang, "Separation and preparation of nobiletin and citrinin in tangerine peel by multi-solvent extraction," Chinese Journal of New Drugs, vol. 26, no. 8, pp. 952-956, 2017.

[83] G. Zheng, D. Yang, F. Zhou, X. Yang, and L. Lin, "Simultaneous determination of five active flavonoids in Rhizoma Citri from different areas by HPLC," Chinese Herbal Medicines, vol. 41, no. 4, pp. 652-655, 2010.

[84] J. P. X. Feng, C. Li, and T. Wang, "Development and research progress of flavonoids in natural products," Guiding Journal of TCM, vol. 24, no. 4, pp. 71-74, 2018.

[85] M.-q. Fu, G.-s. Xiao, J.-j. Wu et al., "Chemical constituents from pericarpium Citri reticulatae," Chinese Herbal Medicines, vol. 9, no. 1, pp. 86-91, 2017.

[86] T. Long, X. Lv, Y. Xu, G. Yang, L.-Y. Xu, and S. Li, "Supercritical fluid $\mathrm{CO}_{2}$ extraction of three polymethoxyflavones from Citri reticulatae pericarpium and subsequent preparative separation by continuous high-speed countercurrent chromatography," Journal of Chromatography B, vol. 1124, pp. 284-289, 2019.

[87] Y. Wang, J. Qian, J. Cao et al., “Antioxidant Capacity, anticancer ability and flavonoids Composition of 35 citrus (citrus reticulata blanco) varieties," Molecules, vol. 22, no. 7, 2017.

[88] J. L. Liu, S. Wang, S. Q. Tian et al., "Nobiletin inhibits breast cancer via p38 mitogen-activated protein kinase, nuclear transcription factor-kappa B, and nuclear factor erythroid 2related factor 2 pathways in MCF-7 cells," Food \& Nutrition Research, vol. 62, 2018.

[89] N. Borah, S. Gunawardana, H. Torres, S. McDonnell, and S. Van Slambrouck, " $5,6,7,3^{\prime}, 4^{\prime}, 5^{\prime}$-Hexamethoxyflavone inhibits growth of triple-negative breast cancer cells via suppression of MAPK and Akt signaling pathways and arresting cell cycle," International Journal of Oncology, vol. 51, no. 6, pp. 1685-1693, 2017.

[90] S. Surichan, V. P. Androutsopoulos, S. Sifakis et al., "Bioactivation of the citrus flavonoid nobiletin by CYP1 enzymes in MCF7 breast adenocarcinoma cells," Food and Chemical Toxicology, vol. 50, no. 9, pp. 3320-3328, 2012.

[91] N. Sp, D. Y. Kang, Y. H. Joung et al., "Nobiletin inhibits angiogenesis by regulating src/FAK/STAT3-mediated signaling through PXN in ER+ breast cancer cells," International Journal of Molecular Sciences, vol. 18, no. 5, 2017.

[92] K. L. Morley, P. J. Ferguson, and J. Koropatnick, “Tangeretin and nobiletin induce G1 cell cycle arrest but not apoptosis in human breast and colon cancer cells," Cancer Letters, vol. 251, no. 1, pp. 168-178, 2007.

[93] H. Zhang, P. Lv, Z. Xiao, E. A. Jothi, and J. Yang, "Nobiletin attenuates cell proliferation by modulating the activating protein-1 signaling pathway in 7,12-dimethylbenz[a]anthracene-induced mammary carcinogenesis," Journal of Environmental Pathology, Toxicology and Oncology, vol. 39, no. 1, pp. 13-21, 2020.

[94] C. Chen, M. Ono, M. Takeshima et al., "Antiproliferative and apoptosis-inducing activity of nobiletin against three subtypes of human breast cancer cell lines," Anticancer Research, vol. 34, no. 4, pp. 1785-1792, 2014.

[95] K. Milde-Langosch, "The Fos family of transcription factors and their role in tumourigenesis," European Journal of Cancer, vol. 41, no. 16, pp. 2449-2461, 2005.

[96] E. Shaulian and M. Karin, "AP-1 as a regulator of cell life and death,” Nature Cell Biology, vol. 4, no. 5, pp. E131-E136, 2002.

[97] C. E. Caldon, R. L. Sutherland, and E. A. Musgrove, "Cell cycle proteins in epithelial cell differentiation: implications for breast cancer," Cell Cycle, vol. 9, no. 10, pp. 1918-1928, 2010.

[98] L. H. Malkas, B. S. Herbert, W. Abdel-Aziz et al., "A cancerassociated PCNA expressed in breast cancer has implications as a potential biomarker," Proceedings of the National Academy of Sciences, vol. 103, no. 51, pp. 19472-19477, 2006.

[99] L. E. Bröker, F. A. E. Kruyt, and G. Giaccone, "Cell death independent of caspases: a review," Clinical Cancer Research, vol. 11, no. 9, pp. 3155-3162, 2005.

[100] Y. Li, X. Liu, and F. Rong, "Puma mediates the apoptotic signal of hypoxia/reoxygenation in Cardiomyocytes through mitochondrial pathway," Shock, vol. 35, no. 6, pp. 579-584, 2011.

[101] X. D. Wang, "The expanding role of mitochondria in apoptosis," Genes \& Development, vol. 15, no. 22, pp. 2922-2933, 2001.

[102] F. Llambi and D. R. Green, "Apoptosis and oncogenesis: give and take in the BCL-2 family," Current Opinion in Genetics \& Development, vol. 21, no. 1, pp. 12-20, 2011.

[103] T. Engel and D. C. Henshall, "Apoptosis, Bcl-2 family proteins and caspases: the ABCs of seizure-damage and epileptogenesis?" International Journal of Physiology, Pathophysiology and Pharmacology, vol. 1, no. 2, pp. 97-115, 2009.

[104] K. Nabeshima, T. Inoue, Y. Shimao, and T. Sameshima, "Matrix metalloproteinases in tumor invasion: role for cell migration," Pathology International, vol. 52, no. 4, pp. 255-264, 2002.

[105] S. R. Mcdougall, A. R. A. Anderson, and M. A. J. Chaplain, "Mathematical modelling of dynamic adaptive tumour-induced angiogenesis: clinical implications and therapeutic targeting strategies," Journal of Theoretical Biology, vol. 241, no. 3, pp. 564-589, 2006.

[106] A. Bast, H. Kaiserová, G. J. M. Hartog, G. R. M. M. Haenen, and W. J. F. Vijgh, "Protectors against doxorubicin-induced cardiotoxicity: flavonoids," Cell Biology and Toxicology, vol. 23 , no. 1, pp. 39-47, 2007.

[107] C. Fimognari, M. Nusse, M. Lenzi et al., "Sulforaphane increases the efficacy of doxorubicin in mouse fibroblasts characterized by p53 mutations," Mutation Research-Fundamental and Molecular Mechanisms of Mutagenesis, vol. 601, no. 1-2, pp. 92-101, 2006.

[108] W. Ma, S. Feng, X. Yao et al., "Nobiletin enhances the efficacy of chemotherapeutic agents in ABCB1 overexpression cancer cells," Scientific Reports, vol. 5, Article ID 18789, 2015.

[109] S. Sangrajrang and A. Fellous, "Taxol resistance," Chemotherapy, vol. 46, no. 5, pp. 327-334, 2000.

[110] J. B. Vaidyanathan and T. Walle, "Cellular uptake and efflux of the Tea flavonoid (-)Epicatechin-3-gallate in the human 
intestinal cell line Caco-2," Journal of Pharmacology and Experimental Therapeutics, vol. 307, no. 2, pp. 745-752, 2003.

[111] O. Kimura, C. Ohta, N. Koga, K. Haraguchi, Y. Kato, and T. Endo, "Carrier-mediated uptake of nobiletin, a citrus polymethoxyflavonoid, in human intestinal Caco-2 cells," Food Chemistry, vol. 154, pp. 145-150, 2014.

[112] A. Murakami, K. Koshimizu, H. Ohigashi et al., "Characteristic rat tissue accumulation of nobiletin, a chemopreventive polymethoxyflavonoid, in comparison with luteolin," Biofactors, vol. 16, no. 3-4, pp. 73-82, 2002.

[113] A. Murakami, Y. Nakamura, K. Torikai et al., "Inhibitory effect of citrus nobiletin on phorbol ester-induced skin inflammation, oxidative stress, and tumor promotion in mice," Cancer Research, vol. 60, no. 18, pp. 5059-5066, 2000.

[114] J. Zheng, M. Song, P. Dong et al., "Identification of novel bioactive metabolites of 5-demethylnobiletin in mice," Molecular Nutrition \& Food Research, vol. 57, no. 11, pp. 1999-2007, 2013.

[115] S. P. Chen, D. C. Cai, K. Pearce et al., "Reinstatement of longterm memory following erasure of its behavioral and synaptic expression in Aplysia," eLife, vol. 3, 2014.

[116] T. Yasuda, Y. Yoshimura, H. Yabuki et al., "Urinary metabolites of nobiletin orally administered to rats," Chemical and Pharmaceutical Bulletin, vol. 51, no. 12, pp. 1426-1428, 2003.

[117] V. M. Breinholt, E. A. Offord, C. Brouwer, S. E. Nielsen, K. Brøsen, and T. Friedberg, "In vitro investigation of cytochrome P450-mediated metabolism of dietary flavonoids," Food and Chemical Toxicology, vol. 40, no. 5, pp. 609-616, 2002.

[118] N. Koga, C. Ohta, Y. Kato et al., "In vitrometabolism of nobiletin, a polymethoxy-flavonoid, by human liver microsomes and cytochrome P450," Xenobiotica, vol. 41, no. 11, pp. 927-933, 2011.

[119] Y. Wang and S. L. Yap, "Identification of nobiletin's metabolites in rat urine using ultraperformance liquid chromatography coupled with electrospray ionization time-offlight mass spectrometry," Drug Metabolism Reviews, vol. 43, p. 67, 2011.

[120] M. V. Selma, J. C. Espín, and F. A. Tomás-Barberán, “Interaction between phenolics and gut microbiota: role in human health," Journal of Agricultural and Food Chemistry, vol. 57, no. 15, pp. 6485-6501, 2009.

[121] P. C. H. Hollman, A. Cassidy, B. Comte et al., "The biological relevance of direct antioxidant effects of polyphenols for Cardiovascular health in humans is not established," The Journal of Nutrition, vol. 141, no. 5, pp. 989S-1009S, 2011.

[122] S. Miyamoto, Y. Yasui, T. Tanaka, H. Ohigashi, and A. Murakami, "Suppressive effects of nobiletin on hyperleptinemia and colitis-related colon carcinogenesis in male ICR mice," Carcinogenesis, vol. 29, no. 5, pp. 1057-1063, 2008.

[123] Y. Wang, J. Xie, Z. Ai, and J. Su, "Nobiletin-loaded micelles reduce ovariectomy-induced bone loss by suppressing osteoclastogenesis," International Journal of Nanomedicine, vol. 14, pp. 7839-7849, 2019.

[124] T. Hattori, H. Tagawa, M. Inai et al., "Transdermal delivery of nobiletin using ionic liquids," Scientific Reports, vol. 9, 2019.

[125] S. Li, M.-H. Pan, C.-Y. Lo et al., "Chemistry and health effects of polymethoxyflavones and hydroxylated polymethoxyflavones," Journal of Functional Foods, vol. 1, no. 1, pp. 2-12, 2009.

[126] R. J. Wani, P. Sharma, H. A. Zhong, and H. Chauhan, "Preparation and characterization of griseofulvin solid dispersions," ASSAY and Drug Development Technologies, vol. 18, no. 3, pp. 109-118, 2020.

[127] A. G. Luque-Alcaraz, J. Lizardi, F. M. Goycoolea et al., "Characterization and antiproliferative activity of nobiletinloaded Chitosan nanoparticles," Journal of Nanomaterials, vol. 2012, Article ID 265161, 2012. 